\title{
The Influence of Local and Non-Local Forcing Effects on the Subtidal Circulation of Patos Lagoon
}

\author{
Osmar O. Möller, Jr. ${ }^{1, *}$, Patrice Castaing ${ }^{2}$, Jean-Claude Salomon ${ }^{3, \dagger}$, and Pascal \\ LAZURE $^{3}$ \\ ${ }^{1}$ Laboratório de Oceanografia Física, Departamento de Física, Universidade do Rio Grande, CP \\ 474, 96200-900 Rio Grande RS, Brazil \\ ${ }^{2}$ Université Bordeaux 1, Département de Géologie et Océanographie, U.M.R. EPOC 5805 CNRS, \\ Avenue des Facultés, 33405 Talence Cedex, France \\ ${ }^{3}$ Direction de l'Environnement Littoral, Service des Applications Operationelles, IFREMER, Centre \\ Brest, BP 70, 29280 Plouzané, France
}

\begin{abstract}
Some basic features concerning the subtidal circulation of Patos Lagoon were studied through time series analysis of wind, freshwater discharge, and water level records, as well as by means of experiments carried out with a 3D numerical model. The results indicate that during low to moderate river discharge the wind is the main forcing mechanism in time scales associated with meteorological fronts. The two types of wind action, local and non-local effects, are distinguished and their relative importance is evaluated. Salt water enters the system due to a combination of both remote and local wind effects that favors the development of a pressure gradient towards the lagoon during southwesterly winds. This situation is reversed when northeasterly winds dominate. In the inner parts of the lagoon, local wind plays the major role by inducing set up/set down oscillations. An upwind return flow is then developed under these conditions. During high flood periods, normally observed in late winter, the circulation is driven by freshwater discharge.
\end{abstract}

\section{Introduction}

Coastal lagoons are generally differentiated from drowned river valley estuaries due to the control of the lagoon morphology on the way they respond to the main forcing mechanisms: the tides, wind, and freshwater discharge (Kjerfve and Magill 1989; Kjerfve 1994). The wind, acting on time scales ranging from a few days to a seasonal basis (Pitts 1989), is considered to exercise major influence on their dynamics due to the fact that the tides are generally of secondary importance and are quickly damped out by frictional effects at the entrance (Kjerfve and Knoppers 1991).

The wind drives circulation through its local and non-local effects. The former is associated with wind that stresses the lagoon waters to form the set up/set down oscillations while the latter is related to coastal water level variations caused by Ekman transport mechanism. The relative importance of the local and far field wind on estuarine circulation has been extensively discussed since the paper of Weisberg (1976). The frequency dependence of their effects have been reported by Elliot and Wang (1978), Smith (1978), and Su and Chen (1992) who have also concluded that the remote

\footnotetext{
* Corresponding author: e-mail: osmar@calvin.ocfis.furg.br.

+ Current address: SEAMER, Quai de la Doune, 29200 Brest, France.
}

forcing was always the dominant one. According to Garvine (1985) the estuarine circulation is normally driven by the far field wind because of the relative shortness of most of the estuaries with respect to the low subtidal wavelength. Non-local forcing is also an important factor in the process of water exchange with the continental shelf for restricted lagoons such as Indian River (Smith 1990a,b), Corpus Christi/Laguna Madre Bays (Smith 1977, 1988), Lake Portchatrain (Chuang and Swenson 1981; Swenson and Chuang 1983), and Great South Bay (Wong 1986, 1993). Most of these studies have indicated that the low frequency motion generated offshore is not affected by the entrance filtering which seems to be also the case of choked lagoons (Kjerfve et al. 1990; Kjerfve and Knoppers 1991). However, according to Kjerfve (1986) and Kjerfve and Magill (1989) choked lagoons are mostly influenced by local winds.

Freshwater discharge contributes to the gravitational circulation scheme and may also produce barotropic signals at seasonal scales (Schroeder and Wiseman 1986). Some short period exchanges having barotropic origin have been reported by Schroeder et al. (1990) who also pointed out the difficulties to resolve river flow effects due to the long time scales involved.

Very little is known about the long-term circulation of Patos Lagoon (Fig. 1a), a shallow and 


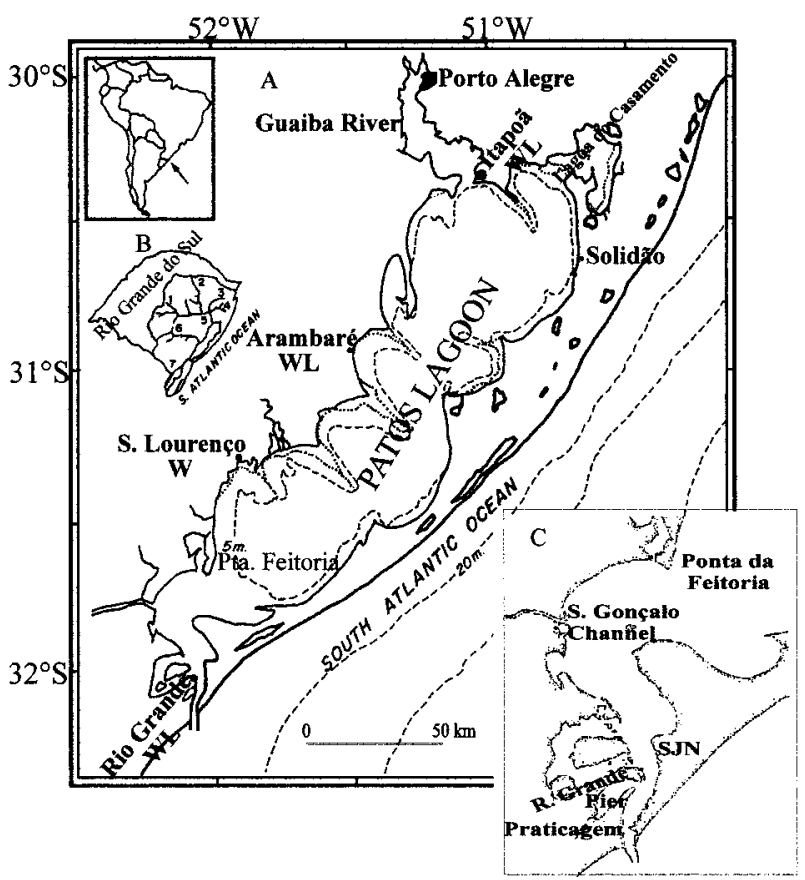

Fig. 1. The study area. A) The Patos Lagoon and the position of water level gauges (WL) and wind recorder (W). B) The hydrographic basin: numbers from 1 to 7 denote, respectively, Jacuí, Taquarí, Sinos, Caí, Guaíba, and Camaquã Rivers and Mirim lake area. C) The estuarine region: names refer to gauge stations or localities mentioned in the text.

choked (Kjerfve 1986) water body located between $30^{\circ} \mathrm{S}$ and $32^{\circ} \mathrm{S}$ in southern Brazil. The great majority of the studies carried out in this region have treated it in a descriptive way and some of them were based on simple statistical methods. Malaval (1922) and Motta (1969) have considered that the circulation of the lagoon was mainly driven by the northeast-southwest dominant wind system. Costa et al. (1988) have found significant relationship between northerly/southerly winds with low/high salinities within the lagoon, and Möller et al. (1991) have shown that for freshwater discharge in excess of $4,000 \mathrm{~m}^{3} \mathrm{~s}^{-1}$ the mixing zone is totally transferred to the inner continental shelf.

More recently Möller et al. (1996) working with a summer data set and a 2D mathematical model have demonstrated the importance of longitudinal local wind to force the set up/set down mechanism of oscillation along the lagoon during the periods of low river contribution. Their results have also shown that filtering at the entrance channel attenuates tides. However, the role and the behavior of long period oscillations generated at the continental shelf as well as the influence of freshwater discharge in the lagoon/shelf exchanges remained unknown.

This paper attempts to go further into these ideas and examines the long period response of Patos Lagoon as a function of local and non-local forcing. In order to assess their relative importance, time series analysis was performed on a year of wind and water level data that were recorded along the entire lagoon and freshwater discharge. It allowed an insight into all the involved frequencies and to determine the existing relationships among the series. The observational results were compared with those produced by a 3D mathematical model (Lazure and Salomon 1991) forced with the observed longitudinal wind and freshwater discharge values. The observed water levels at the entrance of the lagoon were considered as a boundary condition to represent non-local forcing. With this approach it was also possible to observe some processes related with salt transport into the lagoon.

\section{Physical Aspects of the Area}

The Patos Lagoon (Fig. 1a) has a surface area of $10,360 \mathrm{~km}^{2}$ being $250-\mathrm{km}$ long, $40-\mathrm{km}$ wide, and 5 -m deep. It is connected with the South Atlantic Ocean through a 22-km long, 2-km wide, and 12$\mathrm{m}$ deep channel. The main lagoon axis is northeast-southwest oriented coincident with the dominant wind regime.

According to Delaney (1965) the lagoon can be geomorphologically divided in three regions: the lower lagoon, also called the estuarine zone because salt water penetration is generally restricted to this area (Closs 1962; Castello 1985), is the portion situated between the mouth of the lagoon and Ponta da Feitoria; the central lagoon formed by the area between Ponta da Feitoria and the mouth of Lagoa do Casamento; and the upper lagoon that consists of Lagoa do Casamento and the near mouth region of Guaiba River. The lower and central areas are separated by a morphological step, roughly comparable to a deltaic structure by Long (1989), formed by the sandy banks (the local depth is less than $1 \mathrm{~m}$ ) situated around Ponta da Feitoria. The estuarine area (Fig. 1c) occupies approximately one tenth of the total lagoon surface and is characterised by exponential increase of its cross-sectional area with distance away from the mouth. Eighty percent is shallower than $2 \mathrm{~m}$. On the other hand, in the central lagoon region the averaged depth is $5 \mathrm{~m}$. The differences between estuarine and central lagoon are also presented in terms of dynamical processes with faster currents in the southern area. Values around $2.0 \mathrm{~m} \mathrm{~s}^{-1}$ were measured at the entrance channel (Paim and Möller 1986) while in the north maximum current velocities around $0.20 \mathrm{~m} \mathrm{~s}^{-1}$ are attained during strong winds (Niencheski et al. 1988).

Tides are mixed but mainly diurnal having a 
mean range of $0.47 \mathrm{~m}$ and a $\mathrm{F}$ number (Defant 1961) of 2.42 (Herz 1977). The natural period of oscillation of this lagoon, that behaves as a closed system, is around $24 \mathrm{~h}$ and seiches having this period were attributed to the combined effects of sea breeze and the diurnal tide (Möller 1996).

Northeasterly (NE) winds dominate throughout the year. During summer and spring there is also a well marked presence of easterly (E) winds indicating a sea breeze signal influence. Southwesterly (SW) winds have their importance increased during autumn and winter as frontal systems become more frequent over this area. Typical wind speeds are between 3 to $5 \mathrm{~m} \mathrm{~s}^{-1}$ (Tomazelli 1993).

The lagoon drains a hydrographical basin (Fig. 1b) of almost $200,000 \mathrm{~km}^{2}$ formed by rivers which exhibit a typical mid-latitude flow pattern: high discharge in late winter and early spring followed by low to moderate discharge through summer and autumn. They also present large year-to-year discharge variations. The main tributaries are the Guaiba and Camaquã Rivers. The mean annual value is around 2,000 $\mathrm{m}^{3} \mathrm{~s}^{-1}$ (Bordas et al. 1984) with seasonal means ranging from $700 \mathrm{~m}^{3} \mathrm{~s}^{-1}$ during summer up to $3,000 \mathrm{~m}^{3} \mathrm{~s}^{-1}$ in spring. River discharge peaks of 25,000 and $12,000 \mathrm{~m}^{3} \mathrm{~s}^{-1}$ have been observed by Rocheford (1958) and Möller et al. (1991), respectively.

As many coastal lagoons, the Patos Lagoon undergoes large variations of salinity that range from 0 to 34 (Baumgarten 1987). The intensity of the vertical salinity gradient depends on the relative strength of river discharge and wind action (Möller and Castaing 1999). The three main vertical salinity structures described by Cameron and Pritchard (1963), the salt wedge, the partially stratified, and the well mixed type of estuary, can be formed in this area (Calliari 1980; Möller and Castaing 1999). The inner limit of saltwater penetration fluctuates as a function of wind and freshwater regime. During high flood periods the innermost limit position of the mixing zone is totally transferred to the inner continental shelf.

\section{Observations and Treatment of Data}

The main data set used in this study was obtained in 1988. It consisted of time series of hourly water levels at Rio Grande, Arambaré, and Itapoã, wind data recorded at São Lourenço, and freshwater discharge of Guaiba and Camaquã Rivers (see Fig. 1 for reference). Details about the equipment, individual records, and installations can be found in Almeida et al. (1992).

Wind vectors were converted into longitudinal and transversal components through a $37^{\circ}$ clockwise rotation making the y-axis coincident with the main lagoon's orientation and parallel to the coast-
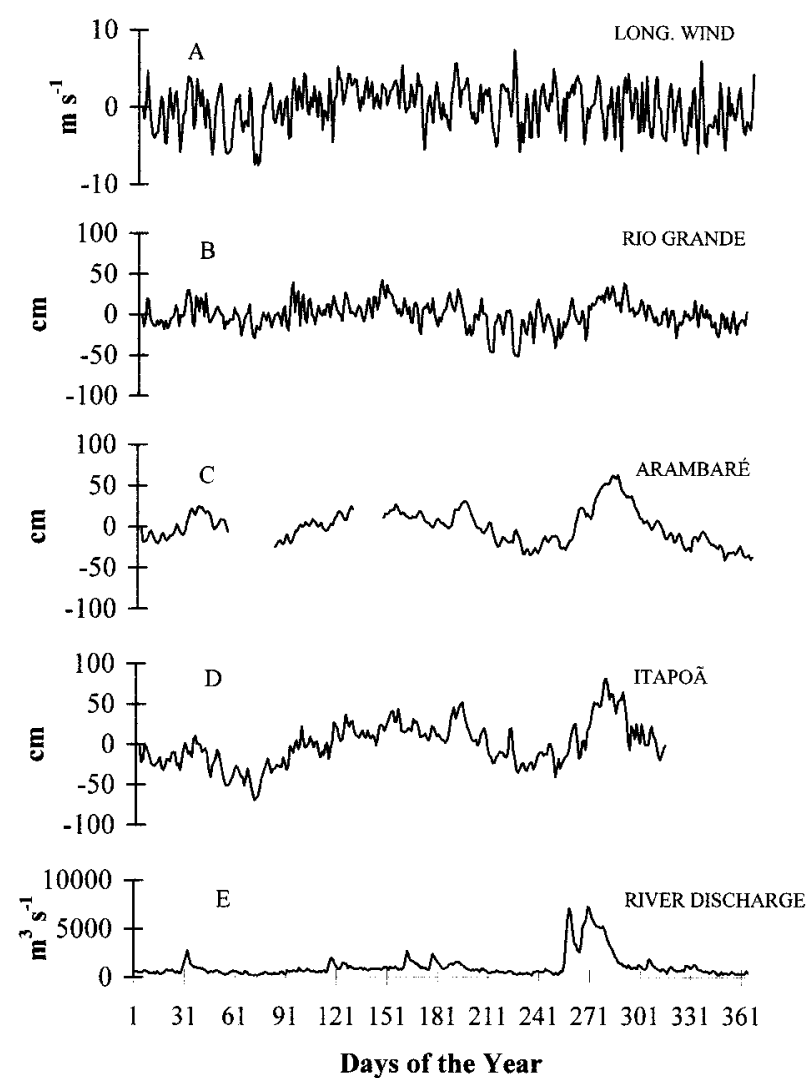

Fig. 2. Filtered time series recorded in 1988: A) longitudinal wind; B, C, D) water level records; E) total river discharge (Jacuí/Taquarí and Camaquã River systems).

line. Positive values indicate for longitudinal and transversal wind components southerly and westerly winds, respectively.

A Lanczos-squared filter with a $95 \%$ cut off period at $24 \mathrm{~h}$ was used to remove high frequency oscillations of both wind and water level series. Spectral and cross spectral analyses were performed with a FFT algorithm (Lorenzzetti 1976).

Daily freshwater discharges for the Camaquã and Jacuí-Taquari River systems were calculated through the rating curve method (Jacobb and Kazimier 1989) using water level values measured by the National Department of Waters and Electrical Energy (DNAEE).

The 1988 daily averaged series used in this study are presented in Fig. 2. Because of the lack of data along the estuarine zone during 1988, a second set, formed by four simultaneous time series of water levels covering a period of $45 \mathrm{~d}$ of hourly recorded values, were analyzed to study the behavior of subtidal oscillations along this region. They were recorded in March-April 1984 by the Office of Hydrography and Navigation (DHN) of the Brazilian Navy at Praticagem, Pier and São José do Norte 
(SJN), and by the Department of Harbours and Rivers of the State of Rio Grande do Sul (DEPREC/RS) at Ponta da Feitoria (Fig. 1c). These series were treated in the same way as those of 1988.

\section{The 3D Model}

The model adopted in this study was described by Lazure and Salomon (1991). It has been already used to simulate the dynamics of Thau lagoon in France (Lazure 1992). The model consists of 2D and 3D automatically coupled models that are formulated in finite differences to solve the complete set of Navier-Stokes equations simplified by the Boussinesq approximation assuming also a hydrostatic balance. Through a sigma coordinate system the number of points in the water column are maintained constant during the vertical discretization. The vertical $\mathrm{z}$ axis is replaced by $\sigma=\zeta+$ $H / D$ where: $\zeta$ is the elevation, $\mathrm{D}$ is the water depth, and $\mathrm{H}$ is the difference between the water depth and the elevation.

The Navier-Stokes and hydrostatic balance equations are formulated as follows:

$$
\begin{aligned}
& \frac{\partial u}{\partial t}+u \frac{\partial u}{\partial x}+v \frac{\partial u}{\partial y}+\omega^{*} \frac{\partial u}{\partial \sigma}-f v \\
&=-\frac{\partial p}{\partial x}+\left(\frac{1}{D^{2}}\right) \frac{\partial}{\partial \sigma}\left[N_{z} \frac{\partial u}{\partial \sigma}\right]+F x \\
& \frac{\partial v}{\partial t}+u \frac{\partial v}{\partial x}+v \frac{\partial v}{\partial y}+\omega^{*} \frac{\partial u}{\partial \sigma}+f u \\
&=-\frac{\partial p}{\partial x}+\left(\frac{1}{D^{2}}\right) \frac{\partial}{\partial \sigma}\left[N_{z} \frac{\partial v}{\partial \sigma}\right]+F y \\
& p=g \zeta+D \int_{\sigma}^{1} b d \sigma
\end{aligned}
$$

where: $\mathrm{u}, \mathrm{v}, \omega^{*}$ are the components of velocity in the $\mathrm{x}, \mathrm{y}$, and $\sigma$ reference system, respectively; $\mathrm{f}$ is the Coriolis term; b is the buoyancy parameter equal to $g\left(\rho_{0}-\rho\right) / \rho_{0}$. Fx and Fy are the diffusion terms that in the new system are functions of the horizontal coefficient of turbulence and of the averaged horizontal velocity squared $\mathrm{U}$ and $\mathrm{V}$ calculated by the 2D model and $\mathrm{Nz}$ is the vertical eddy viscosity.

The Continuity equation is given by:

$$
\frac{\partial \zeta}{\partial \mathrm{t}}+\frac{\partial \mathrm{u}}{\partial \mathrm{x}}+\frac{\partial \mathrm{v}}{\partial \mathrm{y}}+\mathrm{D} \frac{\partial \omega^{*}}{\partial \sigma}=0
$$

The advection/dispersion equation is defined in terms of:

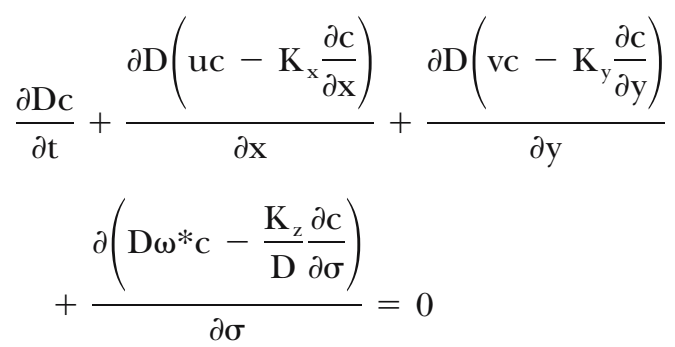

The surface and bottom tensions were parameterised using quadratic formulations of wind and bottom velocities, being $\mathrm{Cd}$, the drag coefficient, given by $0.16\left(\log \mathrm{z} / \mathrm{z}_{0}\right)^{-2}$ where $\mathrm{z}_{0}$ is the roughness factor. Turbulence exchange coefficients are calculated through the mixing length theory. For further details see Lazure and Salomon (1991).

The model domain includes the lagoon, the Guaiba River, and part of the coastal zone discretized in a $2 \mathrm{~km}^{2}$ grid. The nautical charts DHN 2140 and 90 were used to produce the bathymetry (Diretoria de Hidrografia e Navegação 1966, 1969).

The model experiments were carried out with the observed wind, river discharge, and nearmouth water levels collected in 1988. The lagoon was forced with the longitudinal low pass filtered wind observed at São Lourenço and the hourly interpolated values of freshwater discharge introduced at the Guaiba River limits. To test if the wind data observed at São Lourenço could represent the total area a comparison with the longitudinal and transversal wind components measured at Solidão (see Fig. 1a for reference) was carried out. These data were treated in the same way as described earlier and no significant differences exist between these two areas. The same is valid for the transversal wind component. Unfortunately this type of analysis was limited to summer months, and could not be performed with wind stations situated in the southern portion of the lagoon.

The open boundary conditions were prescribed by the low pass filtered water levels recorded at Rio Grande. This gauge station was placed some $20 \mathrm{~km}$ from the entrance which could, of course, have introduced some distortions. However the use of these data was the only way to analyze the remote wind effect within the lagoon.

As initial conditions, salinity distribution was assumed to vary linearly along the estuarine zone in the range from 0 to 33 and a vertically well mixed structure was adopted. It was observed that after 2 $\mathrm{d}$ running the model stratification was developed in the estuarine area.

The agreement between the observed and simulated water levels can be denoted in Fig. 3a,b that presents the plots for Itapoã and Arambaré ob- 


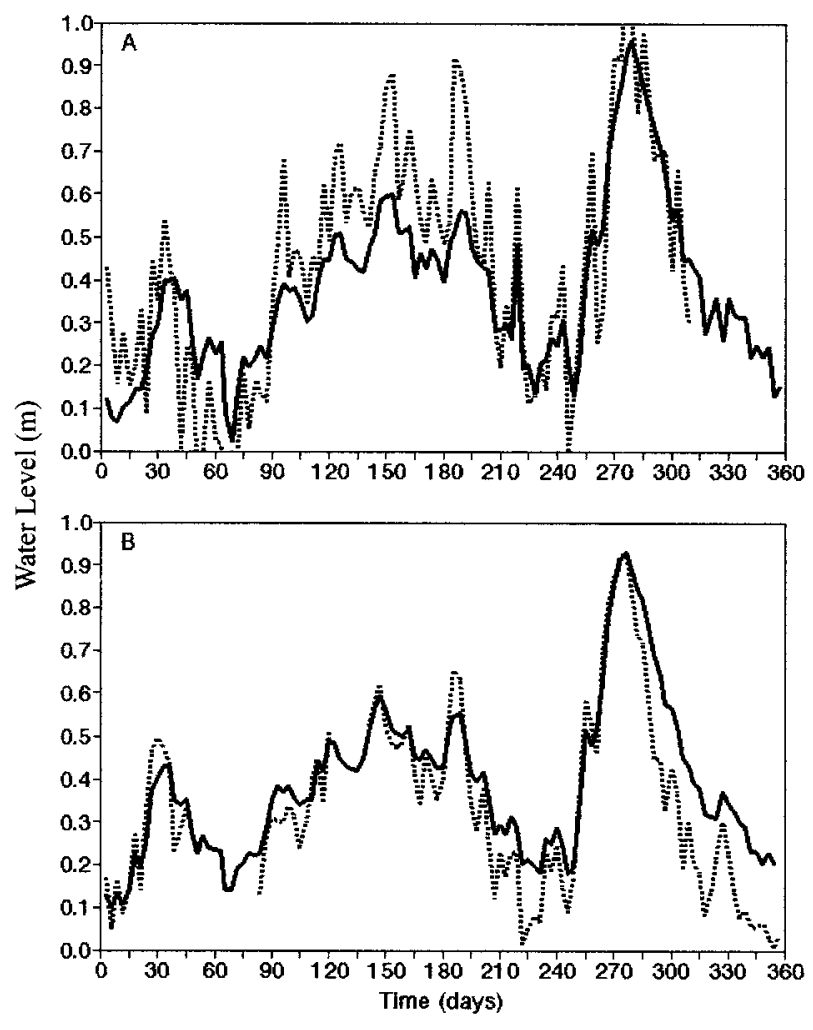

...... Observed Calculated

Fig. 3. Observed and calculated water levels values for Itapoã (A) and Arambaré (B) areas.

tained for a 1988 whole year simulation. The observed and calculated series are well correlated in terms of general features. The disagreement between them may be attributed to the fact that the onshore measured wind data used to force the model was not corrected to account for the differences that may occur with respect to offshore measurements as suggested by Hsu (1986). In the near mouth region (Fig. 4) it was not possible to verify if the results given by the model were correct since apart from Rio Grande water level data used to force the model, there was no other time series available for this area to perform any kind of comparison. In Fig. 5 it can be observed that the signal coming from the ocean is attenuated and in some cases deformed as it progresses towards the inner areas of the lagoon.

\section{Results}

\section{DATA AnAlysis Results}

The time series presented in Fig. 2 had their means and linear trends removed before any kind of analysis. The good correlation between the measured and calculated water levels (Fig. 3) allowed
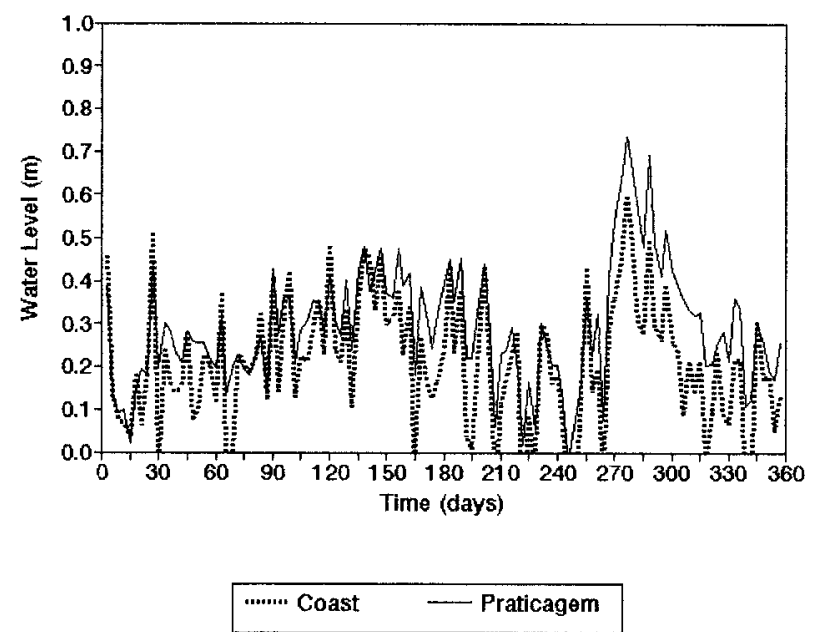

Fig. 4. Calculated water levels for Coastal and Praticagem areas.

to fill the two gaps of Arambaré series (Fig. 2c) and also to complete the data for Itapoã (Fig. 2d) in order to have series of the same length. Spectral and cross spectral analyses were performed with a lag window corresponding to $10 \%$ of the number of data involved. For the 1988 data the corresponding frequency resolution was $0.028 \mathrm{cpd}$ and the number of degrees of freedom was equal to 27.3.
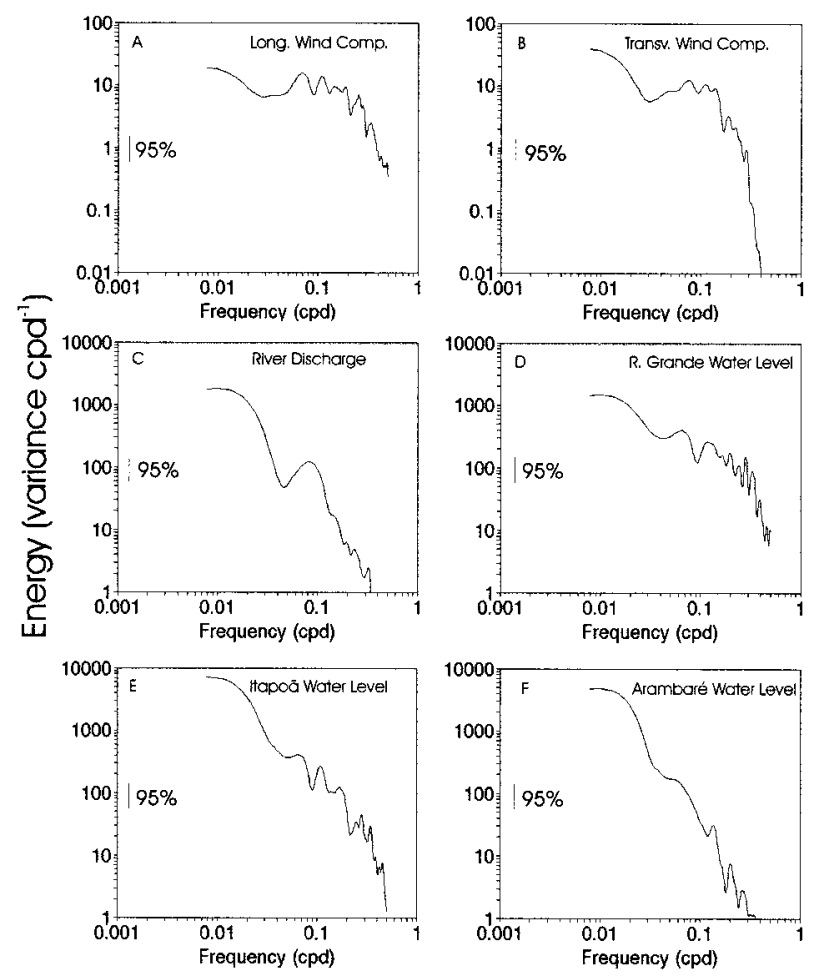

Fig. 5. Energy spectra of the time series recorded in 1988. 


\section{The Spectra}

The curves of the longitudinal (N-S) and transversal $(\mathrm{E}-\mathrm{W})$ wind components spectra are shown in Fig. 5a,b. They are very similar and a cross spectral analysis has revealed that they are coherent and few degrees lagged in the frequency interval between 0.05 to $0.25 \mathrm{cpd}$. However, the energy level of the longitudinal wind component peaks are higher than those observed in the transversal component spectra. Furthermore, a factor analysis carried out to distinguish their relative importance indicate that the E-W component contributes less than $20 \%$ of the total variance. This component, therefore, is neglected in following analysis. The longitudinal component exhibits two significant peaks in the range between 0.05 to $0.13 \mathrm{cpd}$ ( 8 to $20 \mathrm{~d}$ ) and a secondary one centered at $0.25 \mathrm{cpd}$ (4 d). These frequencies can be associated with frontal system passages over this area. A time interval between 3 and $17 \mathrm{~d}$ was obtained through the analysis of synoptic meteorological charts provided by DHN. Spectral analysis also suggests that the along-lagoon wind is dominant at the synoptical periods and the cross-lagoon wind seems to dominate at seasonal periods.

River discharge (Fig. 5c) has its strongest peak centred at the seasonal band $(0.015 \mathrm{cpd})$ and a secondary one around $0.08 \mathrm{cpd}(12.5 \mathrm{~d})$ which seems to be associated with freshets occasioned by meteorological fronts rainfall.

Rio Grande water levels have produced a spectrum (Fig. 5d) with significant energy peaks in the same frequency range than that already observed for the wind. The spectra of Itapoã (Fig. 5e) and Arambaré (Fig. 5f), located in the inner parts of the lagoon, are characterised by strong signals in the lowest frequency band ( $<<0.02 \mathrm{cpd}$ ) but they differ in the region between 0.05 and $0.3 \mathrm{cpd}$. The curve of Itapoã (Fig. 5e) follows that of the wind with the most important peaks ranging from 0.05 to $0.13 \mathrm{cpd}$ while the spectrum of Arambaré is smooth, less energetic, and exhibits a sharp decrease in the same frequency interval. It supports the conclusion given by Möller et al. (1996) that there exists a nodal zone in the vicinities of Arambaré.

\section{Cross Spectral Analysis}

Using the same frequency resolution as before cross spectral analyses were performed between river discharge and wind components against water level series. Freshwater discharge was coherent at $95 \%$ of significance with Itapoã (Fig. 6) and Arambaré (not shown) water levels at the lowest frequencies ( $\mathrm{f}<0.02 \mathrm{cpd}$ ). Concerning Rio Grande (Fig. 6), 47\% of the monthly variance were related

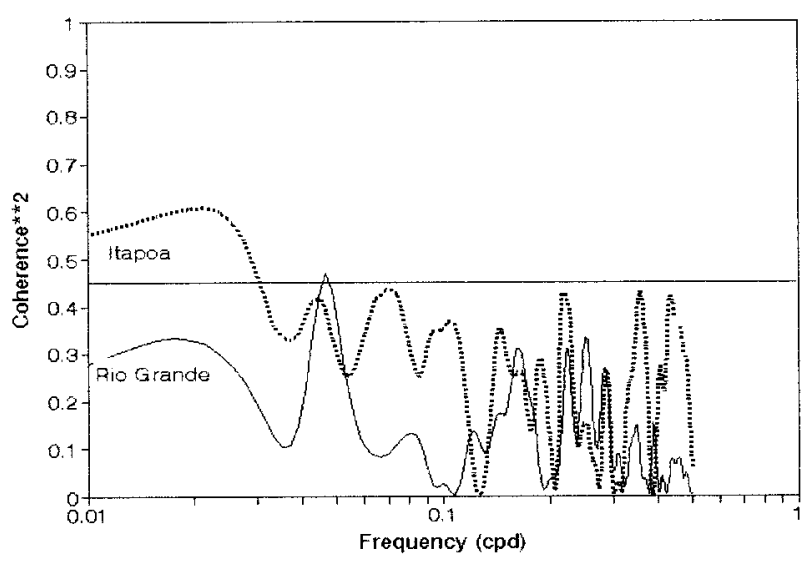

Fig. 6. Coherence squared spectra between river discharge and Rio Grande (solid line) and Itapoã (dotted line) water level series. The $95 \%$ significance level indicated by the straight line is 0.46 .

to freshwater discharge which is slightly above the $95 \%$ significance level of 0.46 .

Wind and water levels were coherent (Fig. 7a) at frequencies between 0.05 and $0.3 \mathrm{cpd}$ for all the series involved. However for Itapoã and Arambaré (not shown) values were significantly greater than those obtained for Rio Grande. In Fig. 7a it is shown that the wind can roughly account for $50 \%$ of the water level variance within the main frequency interval discussed above. Castro and Lee (1995) concluded that sea level fluctuations observed along the southern Brazilian coast were better correlated with winds located southward and earlier in time than with local winds. This can be one of the possible explanations for the low coherence and phase lag (Fig. 7b) found between wind data recorded some $150 \mathrm{~km}$ north from Rio Grande tide gauge. The other possibility can rely on the fact that Rio Grande water level data was recorded in the inner limit of the entrance channel, some $20 \mathrm{~km}$ from the mouth, and could not represent real coastal elevations. In this case, the low coherence values could be associated with inner forced lagoon signals, such as freshwater discharge that could have disturbed the water level oscillations generated at the continental shelf. However, no oceanic data, either wind or water level, were available to allow for a suitable comparison. In Fig. $7 \mathrm{~b}$ it is shown that wind leads Itapoã water level by $35^{\circ}$ in the frequency region of maximum coherence (Fig. 7a).

To investigate the influence of river discharge on the barotropic response of Patos Lagoon two approaches have been used: stepwise regression analysis between longitudinal wind, river discharge, and Rio Grande water level data; and cross spectral analysis performed between wind and the 

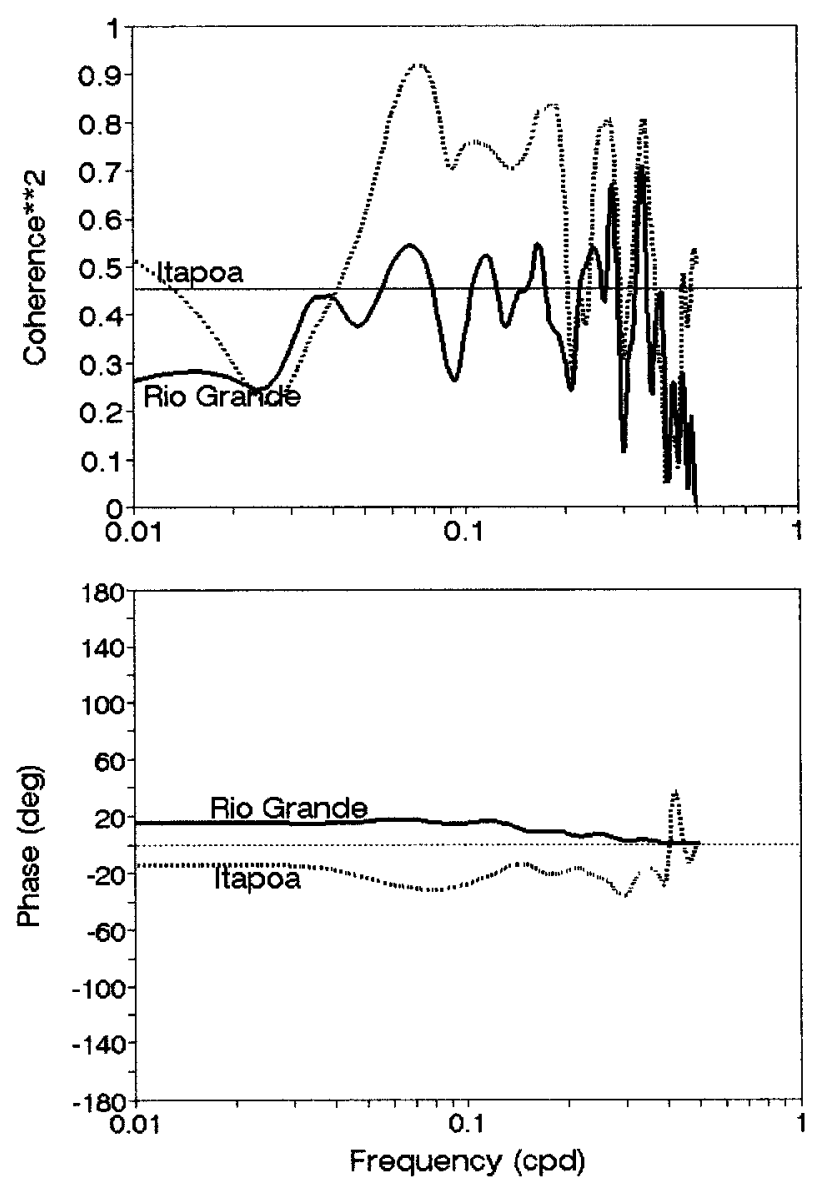

Fig. 7. Coherence squared (A) and phase (B) spectra between longitudinal wind, Rio Grande (solid line) and Itapoã water level (dotted line) time series. The $95 \%$ significance level indicated by the straight line is 0.46 . Negative phase indicates that wind leads water level.

same water level series as before, now separated in seasonal hourly sampled blocks. In both cases means and linear trends were removed from the series and also the flood period data, observed in Fig. 2 between days 260 and 300, were out of consideration. The result obtained through regression analysis is that the $r^{2}$ increases from 0.29 , when only wind data is considered, to 0.33 when river discharge is included in the analysis. The maximum correlation between wind and water level is attained with a lag of $1 \mathrm{~d}$ reaching 0.42 and this value is not significantly altered when river discharge is included. In spite of this result the cross spectral analysis between seasonal blocks of wind and water level data was processed. The aim was to study the relationship between wind and water levels during different river discharge regimes. The seasonal coherence spectra for wind and Rio Grande data are presented in Fig. 8. Coherence values were high for summer and winter months

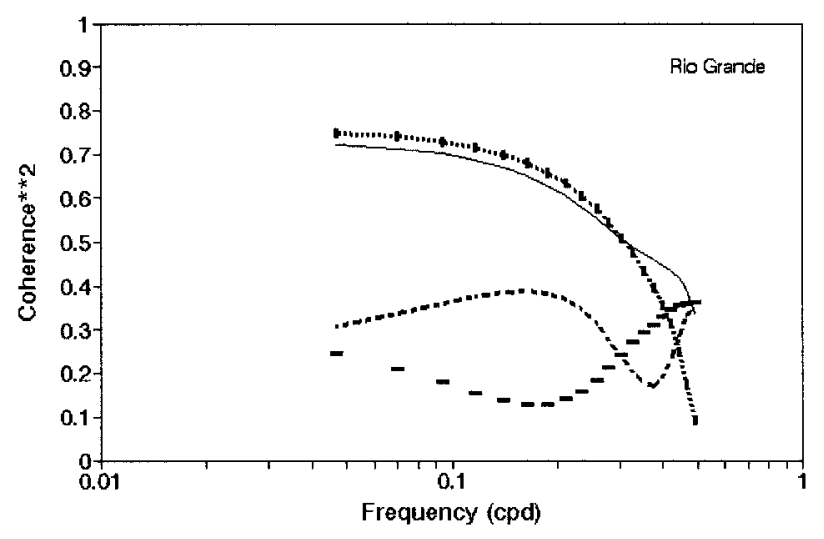

- Summer - Autumn ...... Winter -..- Spring

Fig. 8. Coherence estimates between seasonal blocks of longitudinal wind and Rio Grande water levels.

$\left(\mathrm{Q}<1,000 \mathrm{~m}^{3} \mathrm{~s}^{-1}\right)$ and dropped for autumn $(\mathrm{Q}$ $\left.>1,000 \mathrm{~m}^{3} \mathrm{~s}^{-1}\right)$. It could be an indication of a baseline for river flow action if for late spring, when again $Q$ was lower than $1,000 \mathrm{~m}^{3} \mathrm{~s}^{-1}$, coherence would have increased. However it did not happen and therefore river flow was disregarded as a factor influencing water level oscillations in this near entrance region. The visual inspection of autumn and spring time series did not provide any hint to solve this situation which seems to be due to a few spots where water level responds inversely to wind action.

\section{Subtidal Oscillations in the Estuarine Area}

The records obtained in 1984 at the four gauge stations marked in Fig. 1c (Praticagem, Pier, SJN, and Ponta da Feitoria) were used to study the behavior of the low frequency offshore oscillations into the estuarine zone. Figure 9a, that presents three of the time series used in this analysis, demonstrates that: along the inlet (Praticagem and Pier curves) the amplitude of the water level generated through Ekman transport at the coast decreases; and at Ponta da Feitoria, in the inner limit of the estuarine area, the oscillations are almost symmetric with respect to those observed at the entrance. Spectral and cross spectral analysis may be redundant but they were carried out to quantify the variance and phase changes among these series. The spectral analyses of Fig. $9 \mathrm{~b}$ show the decrease in the water level signal along the estuarine area and confirms the fact that the non-local forced oscillations are attenuated within the estuarine zone. The low coherence values (not shown) and the phase lag of $150^{\circ}$ found between Praticagem and Ponta da Feitoria time series (Fig. 9c) indicate that 

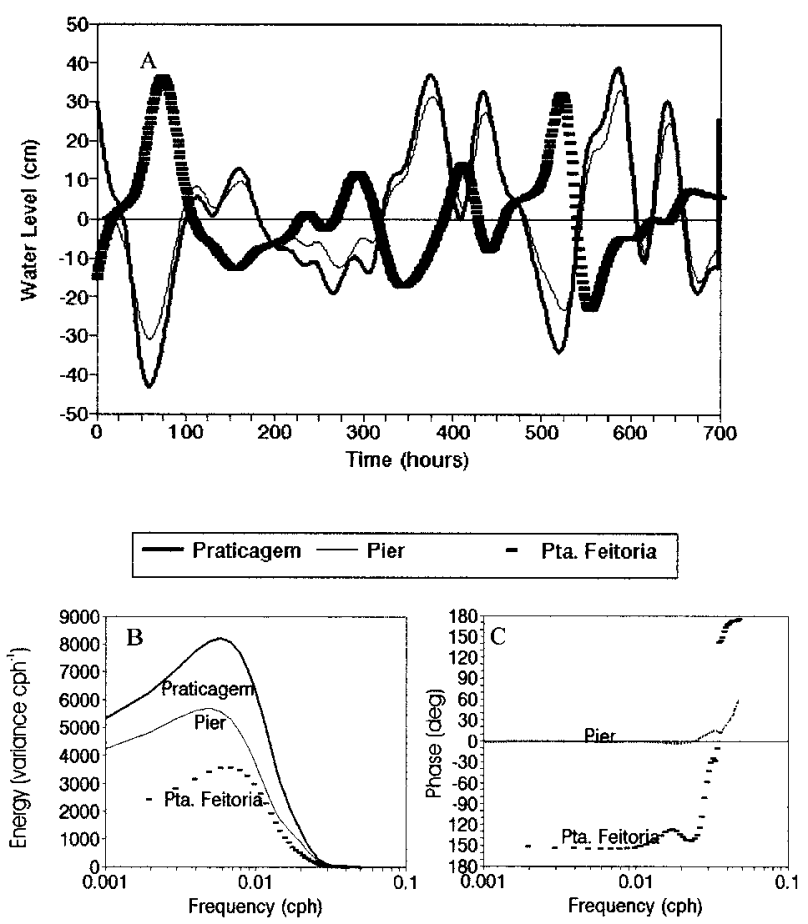

Fig. 9. A) Water level time series recorded within the estuarine area in 1984. To avoid confusion, data from SJN station are not shown. B) Energy spectra of the time series plotted in A. C) Phase spectra of Pier and Ponta da Feitoria records with respect to Praticagem.

different forcing mechanisms act in these two areas. In the entrance channel the non-local wind effect prevails and the areas around and north of Ponta da Feitoria are dominated by the local forcing through the set up/set down mechanism.

\section{Discussion of Observational Results}

The data analysis has revealed several aspects concerning the functioning of Patos Lagoon. The wind acting on time scales associated with frontal system passages is the most important factor that drives the circulation of this system. The local wind effect is responsible for most of the observed water level variance in the central and inner parts of the lagoon and the non-local wind tends to drive the exchanges between the estuarine area and the adjacent continental shelf. There exists a phase difference between these two types of wind effects. Freshwater discharge dominates the dynamics of the whole lagoon during high flood periods.

However, some points could not be elucidated because of data limitations and some questions may arise: what is the factor that breaks down the coherence between wind field and water elevations near the entrance area, what is the maximum limit attained by the sea coming oscillations within the estuarine area, what is the relative importance of
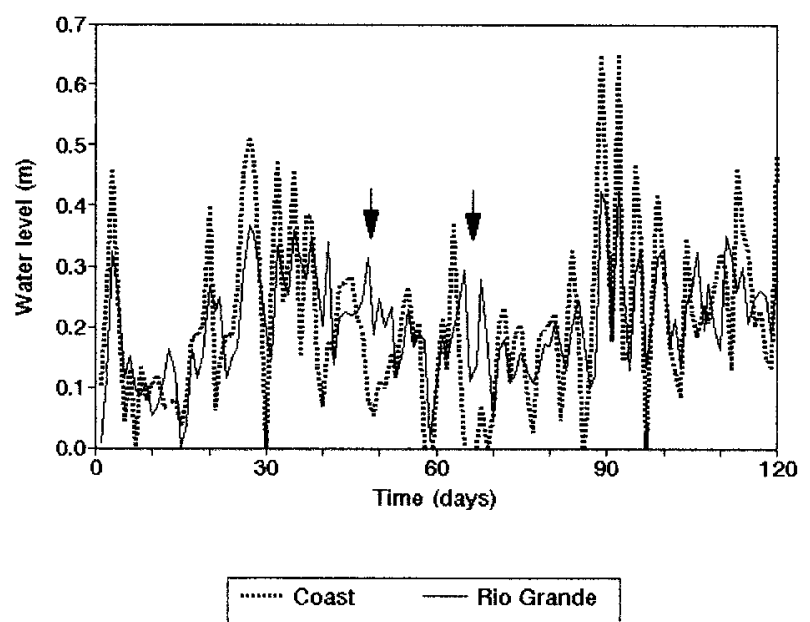

Fig. 10. Calculated water levels for the experiment carried out without river input. Coast water level means the imposed conditions at the boundary. Arrows indicate situations when, at Rio Grande area, the effect of local wind was more pronounced than that of the remote one.

local and non-local wind in the circulation of this area? In order to attempt to answer these questions, several experiments were carried out with a 3D mathematical model.

\section{MOdel Results}

In this section the focus will be centered on the questions that data analysis has failed to answer. They were mainly concerned with processes occurring in the estuarine area. A general overview of the lagoon dynamics will also be presented.

\section{Factors Affecting Wind and Water Level Coherence}

In order to observe how the oceanic originated oscillations could behave in the channel area the model was forced with both wind and water level data recorded between days 3 and 120. The freshwater discharge was set to zero to avoid any kind of interference. The effect it produced was a nonnegligible drop in the mean lagoon level but it has not affected the main features that were mostly associated with the wind field as presented in Figs. 4 and 5. In Fig. 10 the coast time series corresponds to measured water levels imposed as boundary condition while the one indicated as Rio Grande represents the values calculated for a point in the vicinities of this city. It can be observed that coastal water level oscillations are attenuated landwards as established before and, in some cases, they are modified by the effect of the wind blowing along the lagoon. The agreement between these two curves is broken in very few occasions. Two of such situations are marked with arrows in Fig. 10 and denote cases where strong negative (NE) winds (see Fig. 2, days 50 and 70) pile the water up in 
the northern extremity of the channel (Rio Grande). This indicates that the local wind can modify water level oscillations generated at the coastal area through its remote action. At the coast it is expected that the NE wind depresses the water level, however through its local effect it can set the level up in the interior of the estuarine area. This kind of action could have contaminated the data measured at Rio Grande becoming one important factor explaining why the coherence between longitudinal wind and water level recorded in the vicinities of the entrance area is very low.

\section{The Estuarine Area: Local and Non-Local Wind Effects}

Two model experiments have been performed to analyze the way the offshore generated oscillations behave in the estuarine area of Patos Lagoon and, also, to evaluate the relative importance of local and non-local wind effects on the subtidal dynamics of this zone. In the first experiment, only the water level variations were prescribed as boundary conditions. In the second run, the model was forced with the inclusion of the wind field. The wind and water level time series used in these simulations were recorded during a five days cruise onboard RV Larus of Fundação Universidade Federal do Rio Grande (FURG) between April 6 and 11, 1992. A fixed station was occupied in front of Praticagem tide gauge at a depth of $13 \mathrm{~m}$, near the axis of the channel. Salinity, temperature, and current velocity were measured hourly at several depths. Wind data was obtained through a portable anemometer and water level was gauged at Praticagem station within the same time interval as before. Wind vector was converted into longitudinal and transversal components through the axis rotation of $37^{\circ}$ as described earlier. The series presented in Fig. 11a,b are derived from these measurements. For both water elevation and longitudinal wind data, a 5 th order polynomial curve was fitted to remove high frequency oscillations. An example of this filtering method is shown in Fig. 11b for the wind time series. In this picture it can be observed the evolution of a frontal system passage when wind changes from negative values (NE) to positive ones, coming from the southwest. The water level (Fig. 11a) reacts some 15 to $20 \mathrm{~h}$ after the establishment of the southwesterly regime. As the wind speed slows down it no longer sustains the pressure gradient it has created at the coast and, before the establishment of the $\mathrm{NE}$ wind regime at hour 70, the water level decreases indicating a flow reversal. River discharge, calculated in the same way as described earlier was set to $1,400 \mathrm{~m}^{3} \mathrm{~s}^{-1}$.

Figure 12a obtained from the model experiment without wind forcing shows that the long period
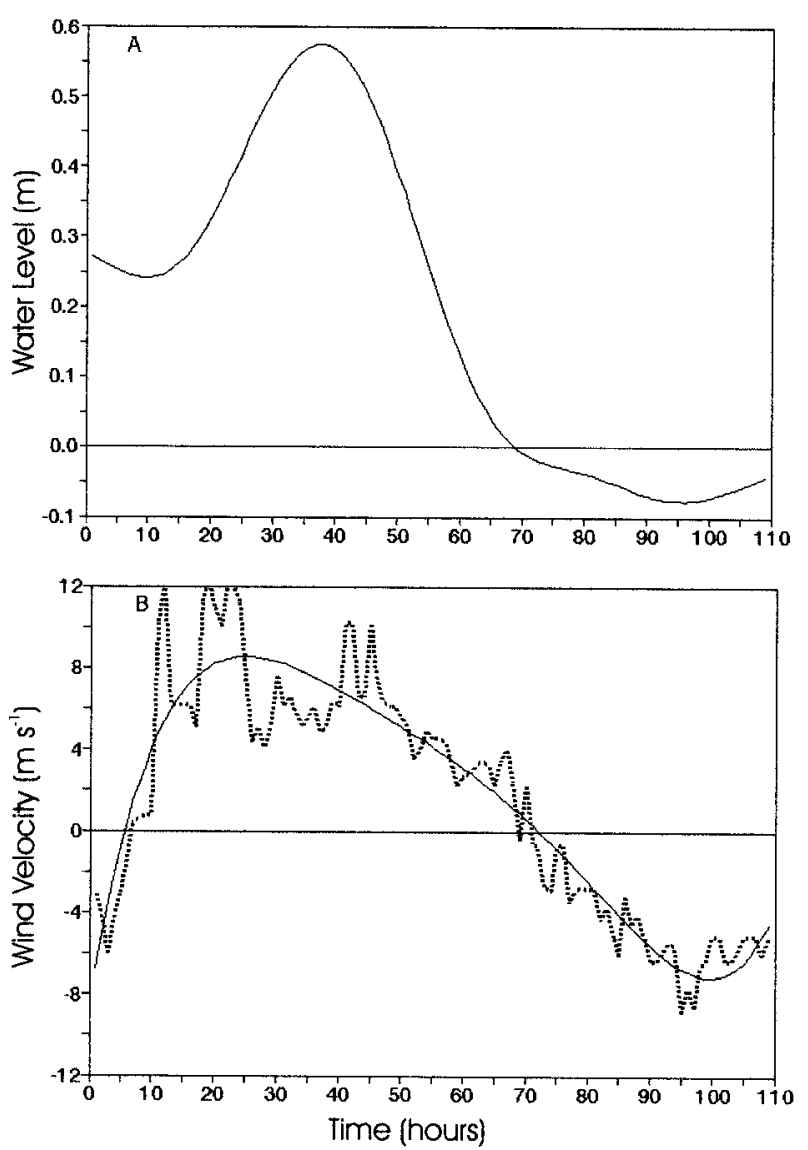

Fig. 11. Data recorded between April 6 and 12, 1992 that were used to force the model: A) Praticagem water level and B) longitudinal wind speed with original (dashed line) and filtered data (continuous line). Praticagem water level is used as reference for the subsequent analysis.

oscillations generated offshore are attenuated as they progress landward. A very weak signal is still present at Ponta da Feitoria region. If it was the only mechanism driving the exchanges with the continental shelf the characteristic salinity curve representing this situation would be that of Fig. $12 \mathrm{~b}$.

When the wind is included a more complex situation is encountered (Fig. 13a,b). Four different processes are clearly identified: the attenuation of the oscillations generated at the coastal area (Fig. 13a, Pier and SJN curves); the water level set up generated along the lagoon by the local wind effect (Fig. 13a, Ponta da Feitoria and Itapoã curves); the phase difference between the local wind effect (Ponta da Feitoria and Itapoã curves) and remote action represented by Praticagem (Fig. 11a) and Pier curves (Fig. 13a); and in the inner limits of the channel area (Fig. 13a, SJN curve) the water levels are affected by local wind being deformed when compared with the same curve of Fig. 12a. 

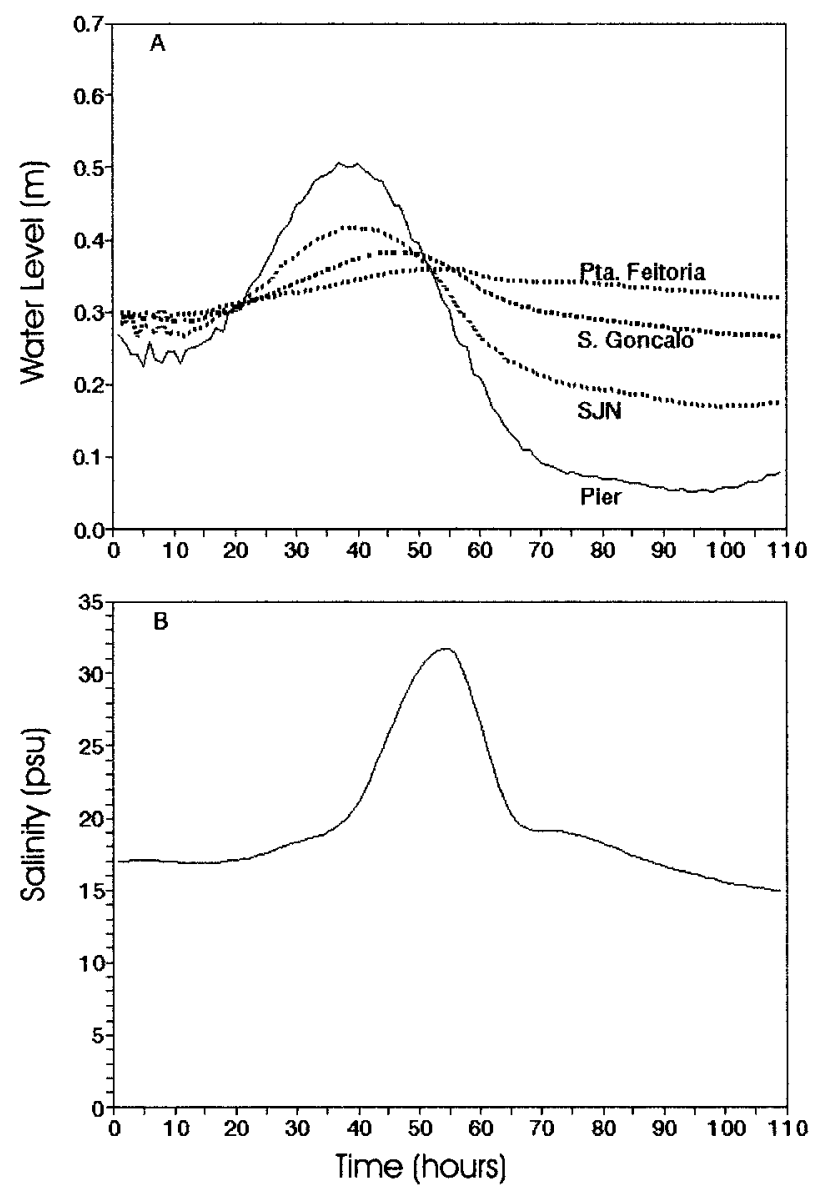

Fig. 12. Plots of the model experiment carried out without considering local wind forcing. Coastal water level (representing non-local wind effect and river discharge were the only imposed as boundary conditions. A) Calculated water levels. B) Calculated surface salinity values at a grid point corresponding to Praticagem area.

It can be observed that the maximum setup is attained $20 \mathrm{~h}$ after the wind reversion and that it is reached some $15 \mathrm{~h}$ before water level at the coast has reached its peak value. After hour 70, the pressure gradient is reversed with water level rising at Ponta da Feitoria and depressing at the coast due to the NE wind influence.

Figure 13b presents the observed superficial salinity data measured at Praticagem and the calculated surface values for the corresponding grid point. The high frequency salinity variations were removed from measured data through a simple 3 points Hanning filter. These curves (Fig. 13b) indicate that local and non-local winds act as complementary effects in the exchanges between the lagoon and the continental shelf. This is clearly due to the phase lag between these two effects on the water level variations. Salt water is introduced into the lagoon by the pressure gradient produced
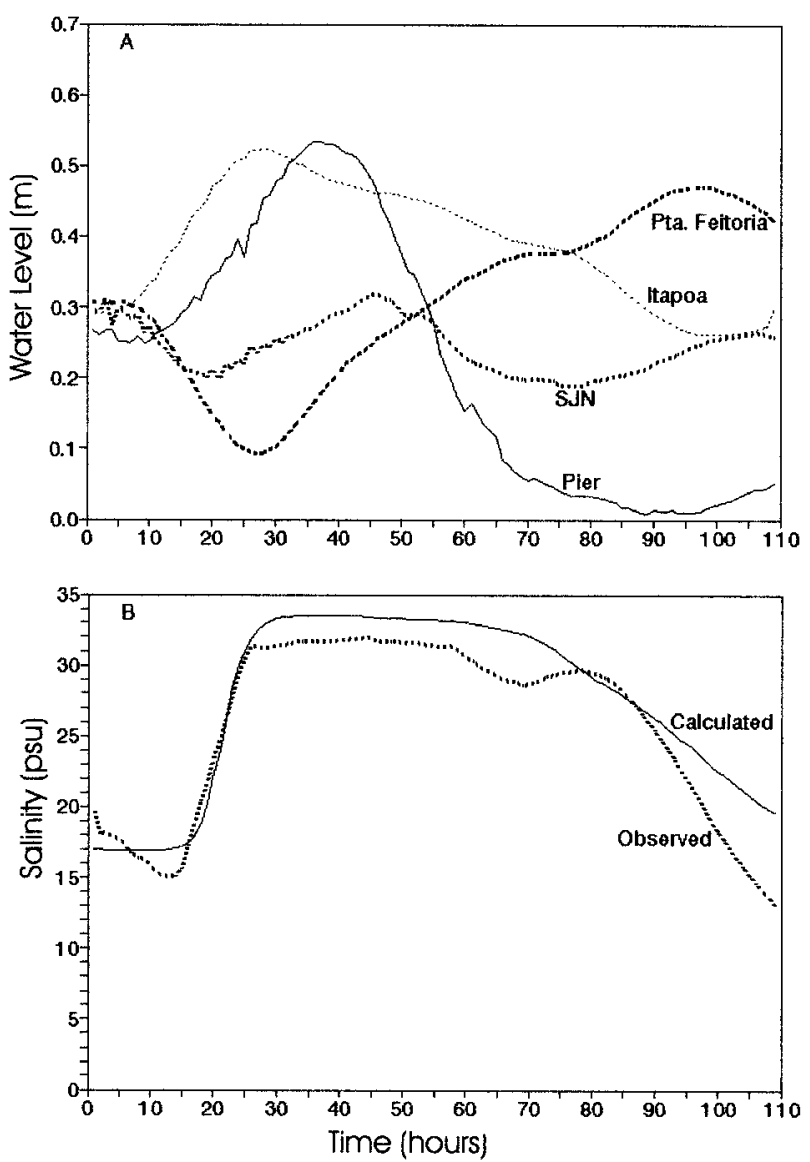

Fig. 13. Plots of the model experiment which included the local wind forcing, the water oscillation at the coast, and river discharge. A) Calculated water levels. B) Calculated and observed surface salinity values at a grid point corresponding to Praticagem area.

by southwesterly winds between the coast and Ponta da Feitoria. It increases the advective salt transport into the lagoon to a more important degree than a single progressive subtidal wave could afford (Fig. 12b). Northeast winds reverse this situation and flush mixed water out of the lagoon. Based on the maximum salinity values attained in the observed data, it is likely that the water discharged to the ocean can return to the estuary in the next SW wind event.

\section{Wind Driven Currents: A General View}

A general scheme of the circulation of this lagoon during SW and NE wind events are shown in Figs. 14 and 15, respectively. These are vector plots obtained during the experiment described above for the periods of maximum flood $(35 \mathrm{~h})$ and ebb velocities $(100 \mathrm{~h})$ for both surface and bottom. The common features between these two situations are: the velocity field intensification that occurs in the area south of Ponta da Feitoria where currents 

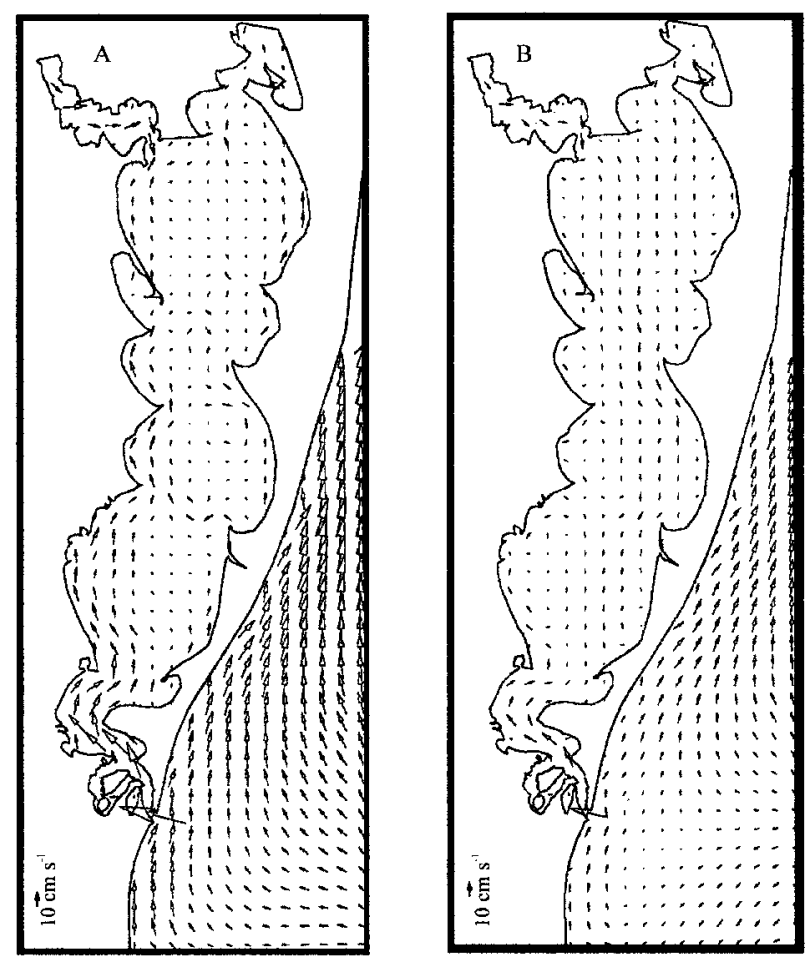

Fig. 14. Plot of surface (A) and bottom (B) currents obtained at hour 35 during a southwest wind event. The model was forced with data recorded between April 6 and 12, 1992.

can attain velocities near $0.80 \mathrm{~m} \mathrm{~s}^{-1}$; in both cases (Figs. 14a and 15a) the strong part of the flow tends to follow the isobaths; and the upwind return flow, which occurs near the bottom (Figs. 14b and $15 \mathrm{~b})$, in the area situated between the northern part of the lagoon and the inner limit of the shallow banks off Ponta da Feitoria pointing out again the importance of this area for the circulation of this lagoon.

However some differences are remarkable. The most important one refers to the presence of gyres during the southwest wind event (Figs. 14a) that are not observed in the situation shown in Fig. 15a. These gyres can be thought of as the combined result of the wind stress and freshwater discharge effects. As the wind action depends on the water depth, in the deeper areas the generated currents are weak and can be almost cancelled out by the opposite river flow induced currents. Near the bottom the river discharge reinforces the upwind return flow (Fig. 14b). In the northeast wind case the opposite situation occurs: at the surface (Fig. 15a) the freshwater discharge reinforces the wind stress currents; at the bottom (Fig. 15b) weak upwind currents weak currents are formed.

\section{Discussion and Conclusions}

The subtidal dynamics of Patos Lagoon can be divided in two distinct periods. Most of the year,
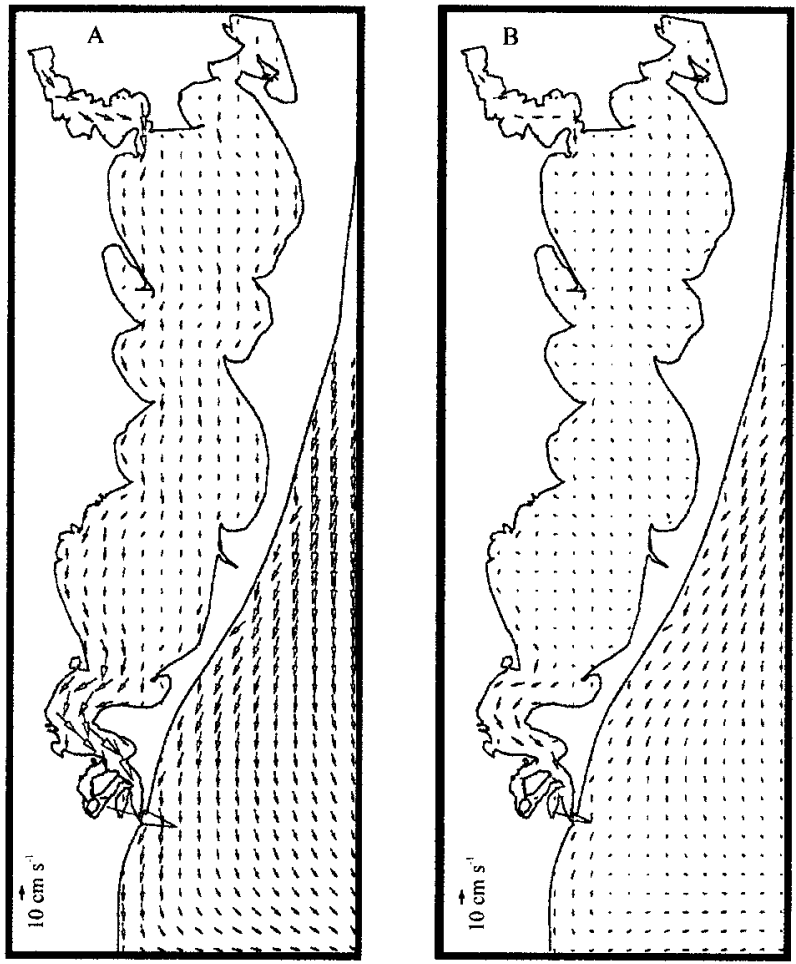

Fig. 15. Plot of surface (A) and bottom (B) currents obtained at hour 100 during a northeast wind event. The model was forced with data recorded between April 6 and 12, 1992

when low to moderate river discharge dominate, the circulation is wind driven, while the river input plays the main role during the annual flood peak in late winter. It can be noticed that in a longer time scale (seasonal period) the influence of river discharge is given by the establishment of a mean water level that can be modulated in a shorter period by the wind regime.

\section{The Wind ACTION}

On the time scales associated with frontal system passages, from 3 to $16 \mathrm{~d}$, the Patos Lagoon dynamics is clearly dominated by the wind action through its longitudinal component that blows parallel to the coast line. In the southern hemisphere, for a system placed in the western margin of the ocean, local and remote winds tend to combine their effects causing the formation of barotropic pressure gradients that produce landward (SW winds) or seaward flows (NE winds). This is rather different from what happens in Chesapeake Bay, in the northern hemisphere, where the local and nonlocal wind fields, also blowing parallel to the coast line, tend to act against each other (Elliot and Wang 1978; Wang and Elliot 1978).

The results also indicate that the existing phase lag between the response of coastal and inner la- 


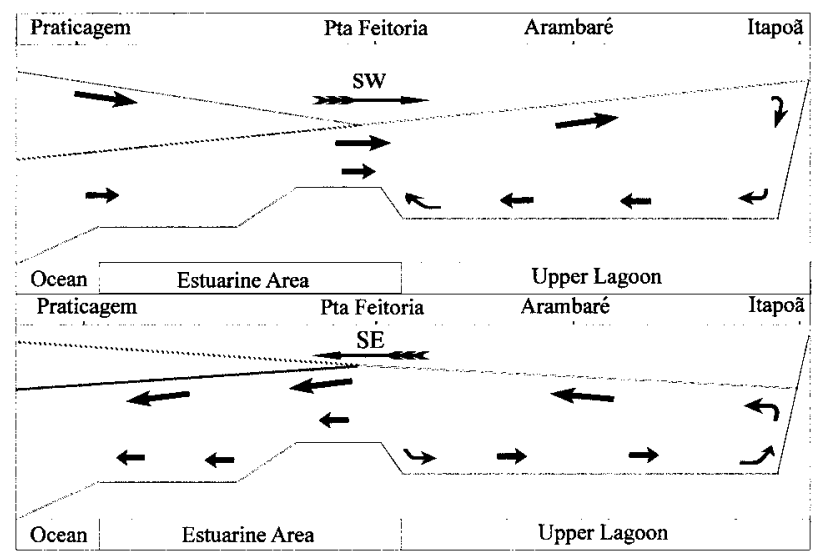

Fig. 16. Schematic representation of Patos Lagoon dynamical behavior when forced with southwest (A) and northeast (B) winds. The dotted line represents the wind set-up if the lagoon was closed at both extremities. This scheme is based on model results presented in Figs. 12, 13, and 14. There is no proportion in arrows denoting currents.

goon waters to the along-shore and along-estuary winds is one important factor controlling the intensity of the interchanges between these two systems. Furthermore, their relative importance on the lagoon-continental shelf exchange processes can be distinguished because of the morphology of the lagoon. The entrance channel not only filters the astronomical tides (Möller et al. 1996) but also attenuates the long period oscillations generated offshore. Therefore, the local wind exercises important influence on the dynamics of the inner lagoon and also on the exchanges with the continental shelf. According to the wind dominant effect three areas can be distinguished: the inlet zone, from the mouth to SJN station, that has its circulation mostly driven by the remote wind action; an intermediate region situated between SJN and Ponta da Feitoria where the local wind dominates circulation but the remote wind still has some influence; and the central and inner lagoon which are driven exclusively by the local wind through the so called set up/set down mechanism of oscillation which has its nodal line around Arambaré.

The limit between the intermediate and inner lagoon areas given by Ponta da Feitoria line is tied to the fact that in this region the maximum or minimum water level values, associated with a certain wind regime, have always been found. This area may be considered to behave as a kind of inflection point (antinodal area) where pressure gradients conditioned by the wind have their signals changed as it has been shown in Fig. 13a. A schematic representation of the wind forced lagoon behavior is presented in Fig. 16 and summarises the results of Figs. 13a, 14, and 15. During SW winds

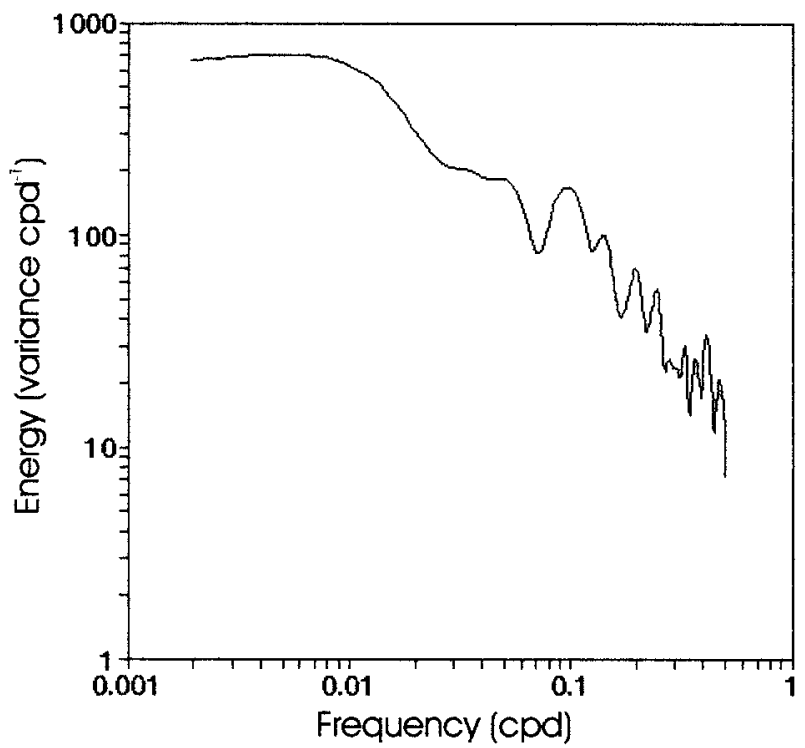

Fig. 17. Spectral curve of the 1983-1985 Praticagem daily recorded salinity time series.

(Fig. 16a) the pressure gradients generated by the combination of remote and local wind effects are directed towards Ponta da Feitoria region. For a $\mathrm{NE}$ wind regime (Fig. 16b) the water level is depressed at both extremities of the lagoon and raised at Ponta da Feitoria. This mechanism that combines non-local and local wind actions is the most important factor that forces the exchanges between the lagoon and the continental shelf. The stronger the wind is, the more important the pressure gradient established between the coast and Ponta da Feitoria region becomes, and so are the processes of water advection in or out of the lagoon. It may be concluded, as well, that in Patos Lagoon the residual flow is normally seaward because of the longer duration and intensity of $\mathrm{NE}$ winds coupled with important contributions from the hydrographical basin.

In the inner extremity of the entrance channel (Rio Grande gauge station) the local wind can produce water level variations of opposite sign than those generated by the remote effect. The results presented here indicate that this situation can occur during very strong wind events and it may be one of the reasons for the low correlation observed between wind and water level in this area. The oscillations generated offshore are also attenuated as they progress in this area.

More interesting is the similarity of the spectral signature when comparing the curves presented in Fig. 5d for Rio Grande water level data and that of Fig. 17. The latter was obtained from daily surface salinity data collected between September 1983 to March 1985 at Praticagem area, which were pub- 
lished by Baumgarten (1987). The same spectral estimates were used in both cases. With the exception of the seasonal peak that may be tied with river flow influence, most of the variance lies on time intervals similar to those found for Rio Grande water levels. It can be seen from this picture that the wind exerts strong control on salinity variations in the channel area. In this sense, this leads to the conclusion presented by Goodrich (1988) that in coastal lagoons meteorologically forced advection is primarily responsible for salinity variance at subtidal time scales. Part of the water mass transferred to the coast during a $\mathrm{NE}$ wind event may return in the next SW wind cycle. According to Abreu et al. (1995) this is a mechanism for reintroducing nutrient rich salt water in this lagoon. As a consequence, it can be conjectured that wind action can also influence chlorophyll $a$ concentrations in the same manner than described by Mitchell (1991) for Bedford Basin, being the dominant factor that induces the displacement and recruitment of marine larval species into the lagoon.

\section{FreshWATER Discharge}

Freshwater discharge dominates circulation during high flood period like that observed in late winter. This situation becomes more dramatic during El Niño periods when due to higher precipitation rates lagoon waters can remain fresh for several months (Paim and Möller 1986). Under normal flow conditions river input induces the mean lagoon water level that is modulated by the wind. During the high flood period, freshwater discharge may produce a superelevation (Mehta 1990) that southwestern winds have to overtake in order to force salt water to enter into this system and only storm conditions can reverse the pressure gradient developed between the lagoon and the coastal area.

In spite of being a time-limited factor, high flood periods can produce important consequences for this environment. Fine suspended sediment particles are not allowed to settle down in the lagoon and instead they are transported to the coastal area to form the large muddy deposits observed by Calliari and Facchin (1993). It may also affect the entrance of larvae that depend on estuarine conditions for their development. For instance, the shrimp larvae tend to enter into the estuary in late spring (from November to December). If it coincides with a situation of high river discharge they may fail to recruit and one of the consequences will be the reduction in shrimp production, a very important resource for local economy. Castello and Möller (1978) have found a 95\% significant negative relationship between rainfall and shrimp capture. On the other hand, high freshwater discharges can rapidly flush the suspended and dissolved pollutants introduced by local industry. It is also a fundamental factor for nutrient enrichment and high primary production values observed at the coast (Castello and Möller 1977; Ciotti et al. 1995).

As a final remark it may be stated that the longterm mean water level difference between the lagoon and the ocean may play an important role in the exchange process between these two systems (Liu 1992). This factor could not be evaluated by the available data set. This aspect and those related with mixing processes are subject of future research.

\section{ACKNOWLEDGMENTS}

The authors would like to express their gratitude to the Comissão Interministerial para os Recursos do Mar (CIRM) and the Fundação de Amparo à Pesquisa do Estado do Rio Grande do Sul (FAPERGS) (contract no. 90.1220.0) for the financial support given during the Patos Lagoon and PLATES projects; Diretoria de Hidrografia e Navegação for providing the water level data along the channel area and to Departamento de Portos, Rios e Canais do Estado do Rio Grande do Sul (Pelotas) for the data of Ponta da Feitoria area; the crew of RV Larus from FURG; Dr. William Wiseman and an anonimous reviewer helped to improve this paper; Dr. Adriano Viana, Dr. Peter Zavialov, and Dr. José Henrique Muelbert for criticising the English of the manuscript. This paper is a part of a DSc. Thesis of O. Möller who was sponsored by CNPq, Conselho Nacional de Desenvolvimento Científico e Tecnológico, under contract no. 200331-92.2.

\section{Literature Cited}

Abreu, P. C., C. Odebrecht, And C. Hartmann. 1995. Nutrientrich saltwater and its influence on the phytoplankton of the Patos lagoon estuary, southern Brazil. Estuarine, Coastal and Shelf Science 40:219-229.

Almeida, L. E., N. L. Rosauro, And L. A. M. Endres. 1992. Banco de Dados de Niveis e Ventos da Lagoa dos Patos. Technical Report, Volume I. Instituto de Pesquisas Hidráulicas da Universidade Federal do Rio Grande do Sul, Porto Alegre, Rio Grande do Sul, Brazil.

Baumgartem, M. G. Z. 1987. Avaliação do Balanus improvisus como indicador dos niveis metálicos do estuário da Lagoa dos Patos (RS-Brasil). M.S. Thesis, Universidade do Rio Grande, Rio Grande, Rio Grande do Sul, Brazil.

Bordas, M. P., A. Casalas, A. Silveira, And M. Gonçalves. 1984. Circulação e dispersão em sistemas costeiros e oceânicos. Caso da Lagoa dos Patos. Technical Report Instituto de Pesquisas Hidráulicas da Universidade Federal do Rio Grande do Sul, Porto Alegre, Rio Grande do Sul, Brazil.

CAlliari, L. J. 1980. Aspectos sedimentológicos e ambientais na região estuarial da Laguna dos Patos. M.S. Thesis, Comissão de Curso de Pós-Graduação em Geociências, Universidade; Federal do Rio Grande do Sul, Porto Alegre, Rio Grande do Sul, Brazil.

Calliari, L. J. And S. FACchin. 1993. Laguna dos Patos. Influência nos depósitos lamíticos costeiros. Pesquisas 20:57-69.

Cameron, W. M. And D. Pritchard. 1963. Estuaries, p. 306-324. In M. N. Hill (ed.), The Sea, Volume II. John Wiley and Sons, New York.

Castello, J. P. 1985. La ecologia de los consumidores del estuario de la Lagoa dos Patos, Brasil, p. 386-406. In A. Yanes Arancibia (ed.), Fish Community Ecology in Estuaries and 
Coastal Lagoons: Towards an Ecosystem Integration. Editora da Universidade Autônoma Nacional do México Press, Mexico.

Castello, J. P. and O. O. Möller. 1977. On the oceanographic conditions in the Rio Grande do Sul state. Atlântica 2:25-110.

Castello, J. P. and O. O. Möller. 1978. On the relationship between rainfall and shrimp production in the estuary of the Patos Lagoon (Rio Grande do Sul, Brazil). Atlântica 3:67-74.

CAstro, B. M. AND T. N. LEE. 1995. Wind forced sea level variability on the southeast brazilian shelf. Journal of Geophysical Research 100:16045-16056.

Chuang, W.-S. AND E. M. Swenson. 1981. Subtidal water level variations in lake Pontchartrain, Louisiana. Journal of Geophysical Research 86:4198-4204.

Ciotti, A. M., C. Odebrecht, G. Filmann, and O. O. Möller. 1995. Freshwater outflow and Subtropical Convergence influence on phytoplankton biomass on the southern Brazilian continental shelf. Continental Shelf Research 15:1737-1756.

Closs, D. 1962. Foraminíferos e tecamebas da Lagoa dos Patos (RGS). Boletim da Escola de Geologia 11:1-51.

Costa, C., U. Seeliger, And P. Kinas. 1988. The effect of wind velocity and direction on the salinity regime in the Lower Patos Lagoon estuary. Ciência e Cultura 40:909-912.

Defant, F. 1961. Physical Oceanography Volume II. Pergamon Press, London.

Delaney, P. 1965. Fisiografia e geologia de superfície da planície costeira do Rio Grande do Sul. Publicação Especial da Escola de Geologia de Porto Alegre 6:1-105.

Diretoria de Hidrografia E NAvegacĩo. 1966. Brasil Costa Sul—da Ilha de Santa Catarina a Maldonado, Nautical Chart 90, second edition. Diretoria de Hidrografia e Navegação.

Diretoria de Hidrografia e NAVEgaÇÃo. 1969. Brasil Costa Sul-Lagoa dos Patos, Nautical Chart 2140, second edition. Diretoria de Hidrografia e Navegação.

Elliot, A. J. AND D.-P. WANG. 1978. The effect of meteorological forcing on the Chesapeake Bay: The coupling between an estuarine system and its adjacent coastal waters, p. 127-145. In J. C. J. Nihoul (ed.), Hydrodynamics of Estuaries and Fjords. Elsevier Oceanographic Series 23, Amsterdam, Netherlands.

GARVINE, R. 1985. A simple model of estuarine subtidal fluctuations forced by local and remote wind stress. Journal of Geophysical Research 90:11945-11948.

GOODRICH, D. M. 1988. On meteorologically induced flushing in three US east coast estuaries. Estuarine and Coastal Marine Science 26:111-121.

Herz, R. 1977. Circulação das Águas de Superfície da Lagoa dos Patos. DSc. Thesis, Universidade Sao Paulo, Brazil.

Hsu, S. A. 1986. Correction of land-based wind data for offshore applications: A further evaluation. Journal of Physical Oceanography 16:390-394.

JACOB, G. AND J. K. Kazimier. 1989. Curva-chave: Análise e Traçado. Technical Report. Departamento Nacional de Águas e Energia Elétrica, Brazil.

KJERFVE, B. 1986. Comparative oceanography of coastal lagoons, p. 63-81. In D. A. Wolfe (ed.), Estuarine Variability. Academic Press, New York.

KJERFve, B. 1994. Coastal lagoons, p. 1-8. In B. Kjerfve (ed.), Coastal Lagoon Processes. Elsevier Oceanographic Series 60, Amsterdam.

KJERFVE, B. AND B. KNOPPERs. 1991. Tidal choking in a coastal lagoon, p. 169-179. In B. Parker (ed.), Tidal Hydrodynamics. John Wiley and Sons, New York.

Kjerfve, B., B. Knoppers, P. Moreira, And B. Turo. 1990. Hydrological regimes in Lagoa de Guarapina, a shallow brazilian coastal lagoon. Acta Limnologica Brasiliensia III:931-949.

KJeRfVE, B. AND K. E. Magill. 1989. Geographic and hydrographic characteristics of shallow coastal lagoons. Marine Geology 88:187-199.
LAZURE, P. 1992. Etude de la dynamique de l'étang de Thau par modèle numérique tridimensionnel. Vie Millieu 42:137-145.

Lazure, P. And J.-C. SAlomon. 1991. Coupled 2D and 3D modelling of coastal hydrodynamics. Oceanologica Acta 14:173-180.

LiU, J. T. 1992. The influence of episodic events on tidal residual currents: A case study at Sebastian Inlet, Florida. Estuaries 15: $109-121$.

LoNG, T. 1989. Le quaternaire littoral du Rio Grande do Sul state temoin des quatres dernieres episodes eustatiques majeurs. Géologie et évolution. DSc. Thesis, Université Bordeaux I, France.

Lorenzzetti, J. A. 1976. Aplicação da Técnica de Analise Espectral Cruzada ao Estudo da Correlação entre as Oscilações de Nivel do Mar Observadas em Cananéia e Bom Abrigo. M.Sc. Thesis, Instituto Oceanográfico da Universidade de São Paulo, Brazil.

Malaval, M. B. 1922. Travaux du port et de la barre de Rio Grande, Brésil. Eyrolles Editeurs, Paris.

Menta, A. J. 1990. Significance of bay superelevation in measurements of sea level changes. Journal of Coastal Research 6: 801-813.

Mitchell, M. R. 1991. The influence of local wind forcing on the low-frequency variations of chlorophyll $a$ in a small marine basin. Continental Shelf Research 11:53-66.

MölleR, O. O. 1996. Hydrodynamique de La Lagune dos Patos. Mésures et modelisation. DSc. Thesis, Université Bordeaux I, France.

Möller, O. O. ANd P. Castaing. 1999. Hydrographical characteristics of the estuarine area of Patos Lagoon $\left(30^{\circ} \mathrm{S}\right.$, Brazil), p. 83-100. In G. M. Perillo, M. C. Piccolo, and M. Pino (eds.), Estuaries of South America: Their Geomorphology and Dynamics. Springer Verlag, Berlin.

Möller, O. O., J. A. Lorenzzetti, J. L. Stech, and M. M. Mata. 1996. The summertime circulation and dynamics of Patos Lagoon. Continental Shelf Research 16:355-351.

Möller, O. O., P. S. PAim, ANd I. SoAREs. 1991. Facteurs et mecanismes de la circulation des eaux dans l'estuaire de la lagune dos Patos. Bulletim Institute de Geologie du Bassin d'Aquitaine 49:15-21.

MotTA, V. F. 1969. Relatório diagnóstico sobre a melhoria e o aprofundamento do canal de acesso pela barra do Rio Grande. Technical Report. Instituto de Pesquisas Hidráulicas da Universidade Federal do rio Grande do Sul, Porto Alegre, Rio Grande do Sul, Brazil.

Niencheski, L. F. H., O. O. Möller, C. Odebrecht, and G. Filmann. 1988. Distribuição espacial de alguns parâmetros físicos e químicos na Lagoa dos Patos-Porto Alegre a Rio Grande, RS (verão 1986). Acta Limnologica Brasiliensis II:7997.

Paim, P. S. ANd O. O. Möller. 1986. Material em suspensão e dissolvido no estuário da Lagoa dos Patos-Fase III. Technical Report, contract Fundação Universidade do Rio Grande, Comissão Interministerial para os Recursos do Mar, Rio Grande, Rio Grande do Sul, Brazil.

PitTs, P. A. 1989. Upwind return flow in a coastal lagoon: Seasonal-scale barotropic transport. Estuaries 12:92-97.

Rochefort, M. 1958. Rapports entre la Pluviosité et l'écoulement dans le Brésil Subtropical et le Brésil Tropical Atlantique. Travaux et Mémoires de l'Institut des Hautes Etudes de l'Amérique Latine, Paris, France.

Schroeder, W. W. AND W. J. Wiseman, JR. 1986. Low-frequency shelf-estuarine exchange processes in Mobile Bay and other estuarine systems on the northern Gulf of Mexico, p. 355367. In D. A. Wolf (ed.), Estuarine Variability. Academic Press, New York.

Schroeder, W. W., W. J. Wiseman, JR., ANd S. P. Dinnel. 1990. Wind and river induced fluctuations in a small, shallow, tributary estuary, p. 482-493. In R. T. Chang (ed.), Residual Cur- 
rents and Long Term Transport, Coastal and Estuarine Studies, 38. American Geophysical Union, Washington.

SмiтH, N. P. 1977. Meteorological and tidal exchanges between Corpus Christ Bay, Texas, and the northwestern Gulf of Mexico. Estuarine and Coastal Marine Science 5:511-520.

SмiтH, N. P. 1978. Long period, estuarine-shelf exchanges in response to meteorological forcing, p. 147-159. In J. C. J. Nihoul (ed.), Hydrodynamics of Estuaries and Fjords. Elsevier Oceanography Series 30, Amsterdam.

Smith, N. P. 1988. The Laguna Madre of Texas: Hydrography of a Hypersaline Lagoon, p. 31-40. In B. Kjerfve (ed.), Hydrodynamics of Estuaries. CRC Press, Boca Raton, Florida.

SMITH, N. P. 1990a. Longitudinal transport in a coastal lagoon. Estuarine, Coastal and Shelf Science 31:835-849.

SMith, N. P. 1990b. Wind domination of residual tidal transport in a coastal lagoon, p. 123-133. In R. T. Cheng (ed.), Residual Currents and Long Term Transport. Coastal and Estuarine Studies 38. Springer Verlag, New York.

Su, J. L. AND W. Chen. 1990. On meteorologically induced subtidal motion in Hangzhou Bay, p. 173-190. In D. Prandle (ed.), Dynamics and Exchanges in Estuaries and the Coastal
Zones, Coastal and Estuarine Studies 40. American Geophysical Union, Washington.

Swenson, E. M. AND W.-S. Chuang. 1983. Tidal and Subtidal water volume exchange in an estuarine system. Estuarine, Coastal and Shelf Science 16:229-240.

Tomazelli, L. J. 1993. O regime de ventos e a taxa de migração de das dunas eólicas costeiras do Rio Grande do Sul, Brasil. Pesquisas 20:18-26.

WANG, D. P. AND A. J. Elliot. 1978. Non tidal variability in Chesapeake Bay and Potomac River: Evidence for non local forcing. Journal of Physical Oceanography 8:225-322.

Weisberg, R. H. 1976. The nontidal flow in the Providence River of Narraganset Bay: A stochastic approach to estuarine circulation. Journal of Physical Oceanography 6:721-734.

WONG, K.-C. 1986. Sea level fluctuations in a coastal lagoon. Estuarine, Coastal and Shelf Science 22:739-752.

WONG, K.-C. 1993. Numerical simulation of the exchange process within a shallow bar-built estuary. Estuaries 16:335-345.

Received for consideration, August 3, 2000 Accepted for publication, November 28, 2000 